\title{
Registration Legality of Deed of Establishment of Limited Partnership from District Court to Ministry of Law and Human Rights

\author{
${ }^{1}$ Student of Master of Notarial \\ Program, Universitas \\ Muhammadiyah Sumatera \\ Utara, Indonesia \\ ${ }^{2,3}$ Lecturer of Law Faculty, \\ Universitas Muhammadiyah \\ Sumatera Utara, Indonesia \\ *dekatika.hukum@gmail.com
}

| Dewi Kartika ${ }^{1, *}$ | Ida Nadirah ${ }^{2}$ | Ramlan ${ }^{3}$ |

\begin{abstract}
Based on Article 23 of the KUHD, registration of the deed of establishment of Limited Partnership (CV) is carried out at the secretariat of the district court where the $C V$ is established. However, since the enactment of the Regulation of Ministry of Law and Human Rights (Permenkumham) No.17/2018, registration of the deed of establishment Limited has been carried out through SABU which is under the auspices of the Directorate General of General Legal Administration, Ministry of Law and Human Rights. The position of Permenkumham No.17/2018 in the hierarchy of legislation in Indonesia is under the KUHD, so the purpose of this study was to determine the legality of the registration deed of $\mathrm{CV}$ from the district court to the ministry of law and human rights. This research uses normative research, with a statutory approach method and the level of legal synchronization, with qualitative analysis. Based on Article I of the Transitional Rules of the 1945 Constitution, the position of the KUHD is still a law, this is emphasized in Article 7 Paragraph (1) of Law No.12 of 2011. So that based on the principle of lex superior derogat legi inferior, then the authorities to carry out and receive registration deed of incorporation $\mathrm{CV}$ is the clerk of the district court where CV is located.

KEYWORDS

Legality; Deed Registration; CV; District Court; Ministry of Law and Human Rights
\end{abstract}

\section{INTRODUCTION}

The limited partnership (CV) is a form of business entity that is widely established by the community and is a popular form of business entity besides limited liability companies. In Article 19 of the KUHD it is emphasized that CV is a company, which in the Regulation of Ministry of Law and Human Rights Number 17 of 2018 uses the term an association formed by lending money, and is established by a person or several allies who are jointly responsible and one or more allies who act as money lender. The provision of capital loans (inbreng), can be in the form of other than money, such as objects or others. ${ }^{1}$

The basis for setting up CV is the same as that of a Firm as regulated in Article 19 to Article 35 of the KUHD, especially CV in Article 19 to Article 21 of the KUHD. CV provisions are regulated among the regulations governing Firma, so the procedure for establishing a CV is the same as that of a Firm. According to Article 16 of the KUHD in conjunction with Article 1618 of the Civil Code, a deed is not required to establish a Firm,

${ }^{1}$ Zainal Asikin and Wira Pria Suhartana, Pengantar Hukum Perusahaan, (Cimanggis - Depok: Prenadamedia Group, 2016), p. 41. 
but Article 22 of the KUHD requires an authentic deed, in this case a Notary deed, a deed is a means of proof for third parties. ${ }^{2}$

Each CV establishment must be made with an authentic deed made by and or in the presence of a Notary who is authorized in the territory of the Republic of Indonesia, what must be done first to establish a CV is to establish the association's charter framework as a reference for making an authentic deed as a deed of establishment by an authorized Notary Public. $^{3}$

Some academics argue that $\mathrm{CV}$ can be established solely on the basis of underhanded agreements, which means that the agreement is sufficiently carried out between complementary and limited allies. While some others argue the opposite, where the establishment of a CV must be through an authentic deed made by or before a Notary, and after that, the deed of establishment of the CV must be registered at the Registrar's Office of the competent District Court and announced in the Supplement to the State Gazette of the Republic of Indonesia. However, in practice in Indonesia, the latter view is commonly practiced. $^{4}$

The registration of the $\mathrm{CV}$ establishment is intended so that the establishment of CV can be organized and run well, in order to protect companies that are run honestly (te goeder trouw) from irresponsible third parties. Janes Sidabalok, as quoted by Rini Fitriani, said that this registration is also very important for a company $(\mathrm{CV})$ that carries out business activities, because company registration $(\mathrm{CV})$ is an identity that legalizes or legalizes a company so that it is recognized by the public. ${ }^{5}$ In this case, the legality of the company must be valid according to laws and regulations, where the company $(\mathrm{CV})$ is protected or covered with various documents until it is legal in the eyes of the government in power at that time.

CV registration based on Article 23 of the KUHD confirms that firm partners are required to register the company establishment deed in the register provided for that at the registrar's office of raad van justitie (district court), the jurisdiction where the partnership is established. This means that after the company is formed, the owners of the company are required to register the deed of incorporation made by a notary at the registrar's office of the district court where the company was founded. ${ }^{6}$

However, based on Article 3 jo with Article 2 letter a, Regulation of the Minister of Law and Human Rights Number 17 of 2018 concerning Registration of Limited Partnership, Firma Alliance, and Civil Alliance (Permenkumham No. 17/2018), that the application for registration of the deed of establishment of $\mathrm{CV}$ is submitted by the Applicant to the Minister of Law and Human Rights through the Business Entity Administration System (SABU).

Then the question is can Permenkumham No. 17/2018 putting aside the KUHD, which until now based on Article I of the Transitional Rules of the 1945 Constitution, the KUHD is still classified as law and is still valid, so what is the legality of registering the deed of CV's establishment.

\footnotetext{
${ }^{2}$ Johannes Ibrahim Kosasih dan Anak Agung Sagung Laksmi Dewi, Problematika Perseroan Komanditer (Commanditaire Vennootschap/CV) Dalam Ranah Hukum Bisnis dan Perbankan, (Bandung: PT. Refika Aditama, 2019), pp. 47-48.

${ }^{3}$ Zainal Asikin dan Wira Pria Suhartana, op.cit., p. 45.

4"All About Perseroan Komanditer (CV)-Pengertian, Seluk Beluk, dan Cara Mendirikan", www.kaskus.co.id/, accessed 27 February 2020.

${ }^{5}$ Rini Fitriani. “Aspek Hukum Legalitas Perusahaan atau Badan Usaha dalam Kegiatan Bisnis”, Jurnal Hukum Samudra Keadilan. Vol. 12, No. 1, 2017, pp. 136-137.

${ }^{6}$ Ramlan, Hukum Perusahaan; Jenis-jenis Perusahaan di Indonesia, (Medan: CV. Pustaka Prima, 2019), p. 137.
} 


\section{RESEARCH METHODS}

The research used is normative legal research, namely legal research which is carried out by examining library materials or mere secondary data. ${ }^{7}$ Arief Sidharta said that normative legal research is a type of research that is commonly carried out in the development of legal science which in the West is also known as legal dogmatics (rechtsdogmatiek). ${ }^{8}$

The approach used in this research is the statute approach and the legal synchronization level approach. A statutory approach in which the researcher must see the law as a closed system which has the following characteristics: a. Comprehensive means that the existing legal norms are logically related to one another, b. All-inclusive that the collection of legal norms is sufficiently capable of accommodating existing legal problems, so that there will be no legal shortages, and c. Systematic that in addition to being linked to one another, these legal norms are also hierarchically arranged. ${ }^{9}$ Meanwhile, the legal synchronization level approach looks at the extent to which written positive laws (laws and regulations) are synchronous (harmonious) with each other, which can be examined vertically and horizontally.

The nature of the research used is descriptive, where the data is deductive based on a general theory or concept that is applied to explain a set of data or to show a comparison/relationship of a data set with other data sets. ${ }^{10}$ Meanwhile, the data sources used are primary data and secondary data. Primary data (field research) is obtained directly from the community, ${ }^{11}$ while secondary data is obtained through the library research. Furthermore, it is analyzed qualitatively, namely data analysis that does not use numbers, but instead provides descriptions in words of findings, and therefore prioritizes the quality/quality of the data, and not the quantity. ${ }^{12}$

\section{RESULTS AND DISCUSSION}

\section{Registration of limited partnership after the enactment of the Regulation of Ministry of Law and Human Rights (Permenkumham) No. 17/2018}

In order to create a decent and prosperous life, people can run businesses in the form of micro, small or medium enterprises, such as by establishing a non-legal entity, either in the form of an individual company, firm, or CV.

According to Ridwan Khairandy, as quoted by Ramlan, a business activity can be said to be a company if it meets the following elements: ${ }^{13}$

a. Forms of business, whether run individually or as a business entity;

b. Doing activities regularly and continuously; and

c. The goal is to seek profit and profit.

According to Abdul R. Sulaiman, et al., As quoted by Ramlan, it is stated that a company can be said in the sense of the word law if it has the following elements: ${ }^{14}$

\footnotetext{
${ }^{7}$ Soerjono Soekanto dan Sri Mamudji, Penelitian Hukum Normatif Suatu Tinjauan Singkat, Cetakan Keenam, (Jakarta: RajaGrafindo Persada, 2003), pp. 13-14, 23.

${ }^{8}$ Bernard Arief Sidharta, "Penelitian Hukum Normatif: Analisis Penelitian Filosofikal dan Dogmatikal", in Sulistyowati Irianto and Shidarta (Editor), Metode Penelitian Hukum Konstelasi dan Refleksi, Cetakan kedua, (Jakarta: Yayasan Pustaka Obor Indonesia, 2011), p. 142.

${ }^{9}$ Peter Mahmud Marzuki, Penelitian Hukum, Cetakan ke 6(Jakarta: Kencana, 2010), p. 302.

${ }^{10}$ Bambang Sunggono, Metodoligi Penelitian Hukum: Suatu Pengantar, Cetakan keempat, (Jakarta: PT RajaGrafindo Persada, 2002), p. 38.

${ }^{11}$ Soerjono Soekanto dan Sri Mamudji, op.cit., p. 12.

${ }^{12}$ H. Salim, HS dan Erlies Septiana Nurbani, Penerapan Hukum Pada Penelitian Disertasi dan Tesis, (Jakarta: PT. RajaGrafindo Persada, 2014), p. 19.

${ }^{13}$ Ramlan, Hukum Dagang; Perkembangan Buku Kesatu Kitab Undang-Undang Hukum Dagang Indonesia, (Malang: Setara Press, 2016), p. 67.
} 
a. Business entity. The legal form shows the legality of the company as a business entity that carries out economic activities. The form of the legal entity is contained in the deed of establishment, or business license;

b. Activities in the economic field. The law does not prohibit, does not conflict with public interests and morals, and is not carried out in an unlawful manner;

c. Continously. Activities are carried out for the period specified in the deed of establishment or business license;

d. Overt. Recognition and justification is made by the government by ratifying the articles of association contained in the deed of establishment, issuance of business licenses, and issuance of business permit places;

e. Profits and / or profits. Obtained based on legality and statutory provisions;

f. Bookkeeping. The truth of the contents of the books and the truth of the supporting evidence.

After the establishment of the company, company registration is also required, this is to provide legal certainty and protect companies that are run honestly from irresponsible third parties. Company registration is also an identity to legalize or legalize the business activities of a company so that it can be recognized by the public.

The registration of deed of establishment of Limited Partnership based on Wetboek van Koophandel or KUHD is located at the District Court where the company was founded, and the registration consists of 2 (two) stages, the first stage is based on Article 23 of the Criminal Code that firms companies are required to register a company establishment deed in a register provided for it was in the Registrar's Office of Raad van Justitie where the jurisdiction of the company was founded. The second stage is based on Article 38 of the KUHD, that the company is obliged to re-register the deed in its entirety along with the permits it has obtained in the register held for that at the Registrar's Office of Raad van Justitie in the jurisdiction where the company's domicile is established, and then announce it in an official newspaper. ${ }^{15}$

Article 2 of Law Number 3 of 1982 explains that the purpose of company registration is to record information materials made correctly from a company and is an official source of information for all interested parties regarding the identity, data and other interests of companies that are listed in the company list. in order to guarantee business certainty.

Based on Law Number 3 of 1982 concerning Company Registration Obligations, the second stage registration obligation as described in Article 38 of the KUHD is no longer carried out at the Registrar's Office of the District Court where the company is established. Company registration is carried out at the company registration office (trading sector), while the registration of the company establishment deed is still at the Registrar's Office at the District Court in accordance with the legal domicile of CV. However, Law Number 3 of 1982 concerning Company Registration Obligations has been revoked and declared no longer valid after the promulgation of Law Number 11 of 2020 concerning Job Creation as stipulated in Article 116 Part Nine, CHAPTER VI concerning Ease of Doing Business.

The registration of deed of establishment based on KUHD has been replaced based on Permenkumham No. 17/2018 and its licensing is regulated based on Government

\footnotetext{
${ }^{14} \mathrm{Ibid}$.

${ }^{15}$ Ramlan, Eka NAM Sihombing, Fajriawati, Muhammad Iqbal, "Registration Legality of Deed of Establishment Through System Administration of Enterprise (The Analysis of Ministry of Law and Human Rights Regulation No. 17 of 2018)", Palarch's Journal of Archaeology of Egypt/Egyptology,Pjaee, 17 (4), 2020, pp. 526-527.
} 
Regulation Number 24 of 2018 concerning Electronically Integrated Licensing Services/OSS (PP No. 24/2018) which regulates provisions regarding: ${ }^{16}$

a. Types of licensing, licensing applicants and licensing issuers;

b. Licensing implementation mechanism, rearrangement of K / L / P functions;

c. Licensing reform; delete, combine, simplify, classify forms and types of permits in the form of a list of permits;

d. OSS; institutions, systems, and funding;

e. Incentives or disincentives for licensing through Online Single Submission (OSS);

f. Solving problems and licensing barriers through OSS;

g. Imposition of sanctions.

Article 6 PP No. 24/2018 explains that Petitioners who can apply for business licenses include:

a. Individual business actors;

b. Non-individual business actors, such as; limited liability companies, public companies, regional public companies, other legal entities owned by the state, public service agencies, broadcasting institutions, business entities established by foundations, cooperatives, limited partnership (Commanditaire Vennootschap), partnership firms (Vennootschap Onder Firma), and civil partnership.

The documents that must be completed in the application for licensing through the OSS system include:

a. The registration of deed of establishment made by and or in the presence of a notary;

b. Registered Certificate from the Directorate General of AHU;

c. Certificate of Domicile CV from the village;

d. CV Taxpayer Identification Number;

e. Persero Identity Card.

Then the OSS institution will issue business permits and issue commercial or operational permits based on commitments, business actors fulfill business license commitments and fulfill commercial or operational license commitments. After that business actors are required to pay PNBP (Non-Tax State Revenue) fees, and then the OSS institution facilitates business actors to obtain business licenses through the OSS system. Ministries, Institutions, Regional Governments supervise the fulfillment of business license commitments and fulfillment of commercial or operational license commitments, payment and implementation.

Legal Considerations for the registration of deed of establishment of a Limited Partnership and its Change from the District Court to the Ministry of Law and Human Rights

Article 20 PP No. 24/2018 states that business entity registration is one part of the implementation of business licensing. So business actors who want to establish a CV, The registration of deed of establishment of Limited Partnership is one of the absolute requirements to get a business license.

The registration of deed of establishment business entity was initially carried out at the Registrar's Office of the District Court in accordance with the legal domicile of CV. However, after the enactment of PP. 24/2018, registration of CV's deed of establishment is

\footnotetext{
${ }^{16}$ Kementerian Koordinator Bidang Perekonomian Republik Indonesia, Pokok-pokok Isi Peraturan Pemerintah Nomor 24 Tahun 2018, Semarang 25 July 2018, p. 9.
} 
carried out through SABU at the Directorate of General Legal Administration of the Ministry of Law and Human Rights.

PP No. 24/2018 in addition to regulating business licensing issues, it also regulates CV registration obligations, as confirmed in Article 15 that:

(1) A limited partnership (commanditaire vennootschap) as referred to in Article 6 Paragraph (3) letter i is a limited partnership (commanditaire vennootschap) which has been registered with the Central Government.

(2) Registration of a limited partnership (commanditaire vennootschap) to the Central Government as referred to in paragraph (1) includes registration of the deed of establishment of a limited partnership (commanditaire vennootschap), amendments to the articles of association of a limited partnership (commanditaire vennootschap) and dissolution of a limited partnership (commanditaire vennootschap) by the ministry. who hold government affairs in the field of law.

(3) Further provisions regarding the registration of a limited partnership (commanditaire vennootschap) as referred to in paragraph (1) shall be regulated in a ministerial regulation administering government affairs in the field of law.

As a follow up to the implementation of PP. 24/2018 formed and promulgated Permenkumham No. 17/2018. Establishment of CV before the existence of Permenkumham No. 17/2018 is relatively easier and simpler. Because only with an authentic deed made by a Notary, and registered at the Registrar's Office of the District Court in accordance with the legal domicile of the association, the CV can be run.

However, with the issuance of Permenkumham No. 17/2018 confuses business actors and also notaries, who in this case are the parties who play a role and are responsible for registering CVs in the registration form or $\mathrm{CV}$ change form at the Directorate General of General Law Administration of the Republic of Indonesia through SABU.

The issuance of Permenkumham No. 17/2018 makes overlapping regulations regarding $\mathrm{CV}$ registration, based on Article 23 of the KUHD registration of the deed of CV is carried out at the Registrar's Office (Raad Van Justitie) in accordance with CV's legal domicile, while based on Permenkumham No. 17/2018, registration of CV's deed of establishment is carried out through SABU at the Directorate of General Legal Administration of the Ministry of Law and Human Rights.

Referring to Law Number 12 of 2011 concerning the Formation of Legislative Regulations (Law No.12 / 2011), the KUHD in the type and hierarchy of the Prevailing Laws in Indonesia has a higher status than the position of Permenkumham No. . 17/2018. Soerjono Soekanto as quoted by I Kadek Setiawan said that the formation of laws and regulations must pay attention to the principles of statutory regulations, including the lex specialis derogat legi generalis principle, where special regulations can override general regulations, but this principle can only be applied to parallel regulations., which means law with law, not law with ministerial regulations. Furthermore, the principle of lex superiori derogat legi inferiori, in which laws made by higher authorities have a high position as well. ${ }^{17}$

${ }^{17}$ I Kadek Setiawan, "Inkonsistensi Pengaturan dalam Pelaksanaan Kewenangan dan Biaya Pemberian Izin Usaha Mikro", Jurnal Legislasi Indonesia, Vol. 14, No. 3, 2017, p. 340. 


\section{Legal Considerations for the registration of deed of establishment of a Limited Partnership and its Change from the District Court to the Ministry of Law and Human Rights}

The KUHD in the hierarchy of statutory regulations in Indonesia is based on its position equal to law. As regulated in Article 7 Paragraph (1) of Law no. 12/2011, which states that the types and hierarchy of the Prevailing Laws consist of:

a. The 1945 Constitution of the Republic of Indonesia;

b. Decree of the People's Consultative Assembly;

c. Laws / Government Regulations in Lieu of Laws;

d. Government regulations;

e. Presidential decree;

f. Provincial regulations; and

g. Regency / City regional regulations.

Based on the provisions of this article, the KUHD has a legal position and has a lower position than the 1945 Constitution of the Republic of Indonesia and the Decree of the People's Consultative Assembly. Even though the KUHD is a product of Dutch heritage, and its position is equal to the law, in its rules it cannot contradict the 1945 Constitution of the Republic of Indonesia and the Decrees of the People's Consultative Assembly.

As for the position of the Regulation of the Minister of Law and Human Rights, the statutory regulations can be seen in the provisions of Article 8 Paragraph (1) of Law no. $12 / 2011$, which states that the types of laws and regulations other than those referred to in Article 7 Paragraph (1) also include regulations stipulated by; People's Consultative Assembly, House of Representatives, Regional Representative Council, Supreme Court, Constitutional Court, Supreme Audit Agency, Judicial Commission. Bank Indonesia (BI), The Minister, Agencies, Institutions or commissions at the same level as established by law, the Provincial Regional People's Representative Council, the Governor, the Regency / City Regional People's Representative Council, the Regent / Mayor and the Village Head or equivalent.

Based on the provisions of Article 8 Paragraph (1), the Ministerial Regulation is established by means of a Law Order. So in other words it can be understood that Ministerial Regulations have a lower position than laws. ${ }^{18}$

An explanation regarding the purpose of Article 8 Paragraph (1) of Law no. 12/2011, what is meant by "Ministerial Regulation" is a regulation stipulated by the Minister based on material content in the context of carrying out certain affairs in government ". Article 8 Paragraph (2) Law no. 12/2011 confirms that:

(2) The existence of statutory regulations as referred to in paragraph (1) is recognized and has binding legal force as long as it is ordered by a higher level of statutory regulations or is established based on authority.

From the above provisions, there are 2 (two) requirements for the regulations referred to in Article 8 Paragraph (1) of Law no. 12/2011 has binding power as statutory regulations, namely: ${ }^{19}$

a. Ordered by a higher statutory regulation, or

\footnotetext{
${ }^{18}$ Ketut Caturyani Maharni Partyani, "Pertentangan Norma Dalam Pengaturan Pendaftaran dan Pendirian Commanditaire Vennootschap (CV)", Vyavahara Duta Jurnal Ilmiah Ilmu Agama dan Ilmu Hukum, Vol. 14 No. 1, March 2019, p. 74.

19“Kedudukan Peraturan Menteri Dalam Hierarki Peraturan Perundang-undangan", https://m.hukumonline.com, accessed 05 August 2020.
} 
b. Formed based on authority.

In doctrine, only 2 (two) kinds of statutory regulations are known from the basis of the authority for their formation, namely statutory regulations established on the basis of: ${ }^{20}$

a. Attribution of the formation of laws and regulations, and

b. Delegation of the formation of laws and regulations.

A. Hamid S. Attamimi as quoted by Bilal Dewansyah emphasized that the attribution of statutory authority is defined as the creation of (new) authority by the constitution / grondwet or by the legislators (wetgever) given to a state organ, both existing and existing ones. formed recently for that. ${ }^{21}$

Regarding the existence and binding power of statutory regulations stipulated in Article 8 Paragraph (1) of Law no. 12/2011, including regarding Ministerial Regulation, Article 8 Paragraph (2) of Law no. 12/2011 does not only regulate the existence of laws and regulations on the basis of delegation (regulations that are ordered by a higher level of legislation). Article 8 Paragraph (2) Law no. 12/2011 also confirms the existence of laws and regulations that are established on the basis of authority. ${ }^{22}$

The term "authority" in these provisions, of course, is not the authority to form regulations but authority in other domains. For example, the Minister exercises the authority over certain government affairs which is the power of the President, which means that if the Minister forms a Ministerial Regulation without any "orders from higher laws and regulations". Then the Ministerial Regulation is still categorized as statutory regulation. Whereas in doctrine there is no known type of statutory regulation as such. ${ }^{23}$

When it is related to the Stufen Theorie concept introduced by Hans Kelsen and Hans Nawiasky, that in the science of legislation it is known as hierarchy theory, according to Jimly Asshiddiqie and M. Ali Safa'at as quoted by Zaka Firma Aditya and M. Reza Winata that "the legal system arranged in a tiered and stratified like a rung". ${ }^{24}$ The relationship between norms governing the actions of other norms and other norms is referred to as super-relationship and subordination in a special context.

Farida Indrati said that the norm that determines the actions of other norms is superior, while the norm that performs actions is called the inferior norm. Therefore, actions carried out by higher (superior) norms become the reason for the validity of the entire legal system that forms one unit. ${ }^{25}$

In forming laws and regulations it is carried out based on the principles of good formation, namely clarity of objectives, institutions, or appropriate forming officials, conformity between types, hierarchy and content, enforceability, efficiency, clarity of formulation and openness.

The principles which form the basis of a regulation include; Lex Superior Derogat legi Inferiori, Lex Specialis Derogat legi Generalis, and Lex Posterior Derogat legi Priori. ${ }^{26}$ In the event of a conflict between 2 (two) regulations that govern the same, the principles will emerge and appear in accordance with their designation to ensure which of these laws must be used as a reference. This is why the principle of law is often referred to as legal remedies. Based on the description, it can be said that legal principles give birth to legal norms, and legal norms give birth to legal rules.

\footnotetext{
${ }^{20}$ Ibid.

${ }^{21}$ Ibid.

22 Ibid.

${ }^{23}$ Ibid.

${ }^{24}$ Zaka Firma Aditya dan M. Reza Winata, "Rekonstruksi Hierarki Peraturan Perundang-undangan di Indonesia", Jurnal Negara Hukum, Vol. 9, No. 1, 2018, p. 80.

${ }^{25}$ Ibid.

${ }^{26}$ Bagir Manan, Hukum Positif Indonesia, (Yogyakarta: UII Press, 2004), pp. 58-59.
} 
Hans Kelsen as quoted by Rusdianto Sesung and Muhammad Iqbal stated that: ${ }^{27}$

"The unity of these norms is constituted by the fact that the creation of the norm the lower one-is determined by another- the higher-the creation of which of determined by a still higher norm, and that this regressus is terminated by a highest, the basic norm which, being the supreme reason of validity of the whole legal order, constitutes its unity".

Based on Hans Kelsen's opinion, it can be interpreted that the lowest norm must adhere to a higher legal norm, and the highest legal rule (such as the constitution) must adhere to the most basic legal norm (grandnorm), which is not concrete (abstract), and in the concept of abstract legal norms in Indonesia is Pancasila.

To resolve the conflict of norms, it is necessary to refer to Hans Kelsen's theory of norm gap (Stufen Theory). Hans Kelsen also explained that norms (including legal norms) are tiered and layered in a hierarchical order, where a lower norm applies, originates and is based on higher norms. ${ }^{28}$ Higher norms apply, originate from and are based on even higher norms, and so on until a norm that can be further explored and is hypothetical and fictitious, namely grundnorm (basic norm). ${ }^{29}$ All norms that ultimately rest on the same grundnorm will build a system of norms (and in turn also a legal system) that is complete. ${ }^{30}$

Based on the description above, it can be said that Permenkumham No. 17/2018 contradicts the KUHD. Article 7 Paragraph (1) Law no. 12/2011, it has been seen that the position of the KUHD which is equalized by law, hierarchically has a higher position than the position of the Ministerial Regulation. As stated in Article 7 Paragraph (2) in conjunction with Article 5 letter c Law no. 12/2011 explains that: "The strength of statutory regulations is in accordance with the hierarchy as referred to in paragraph (1)".

According to Article 5 of Law no. 12/2011 that in the formation of statutory regulations, it must be carried out based on the principle of forming good laws and regulations, which include; Clarity of purpose, appropriate institutional or forming officials, suitability between types, hierarchy, and content material, workability, efficiency and efficiency, clarity of formulation, and openness.

Elucidation in Article 5 letter c Law no. 12/2011 explains that what is meant by "the principle of conformity between types, hierarchy and content of content" is that in the Formation of Legislations, one must pay attention to the appropriate content material in accordance with the type and hierarchy of the Legislation.

Based on Article 5 of Law no. 12/2011, the elements in the formation of statutory regulations must be fulfilled so that these laws and regulations can be implemented and are useful for public order. Therefore, in the process of forming laws, it is necessary to pay attention to the legal basis for the formation of a law or other statutory regulations on which it is based. This means that the hierarchy of laws and regulations as regulated in Article 7 of Law no. 12/2011 must be obeyed.

According to Ni'matul Huda, as quoted by Zaka Firma Aditya and M. Reza Winata, it was stated that if the lower laws and regulations contradict those above, then the regulation can be sued to be canceled or null and void by law (van rechtswegenietig). This may imply that lower-level regulations must not conflict with higher-level laws and regulations.

\footnotetext{
${ }^{27}$ Rusdianto Sesung dan Muhammad Iqbal, "Legal Consequences Embedded on the Charity Institution Due to Uncompleted Synchronization Based on Constitution Number 28 Year 2014", International Jurnal of Science and Research (IJSR), Vol. 7, Issue 2, 2018, p. 62.

${ }^{28}$ Maria Farida Indriati, Ilmu Perundang-Undangan 1, (Jakarta: Kanisius, 2013), hlm. 41.

29 Yuliandri, Asas-Asas Pembentukan Peraturan Perundang-Undangan Yang Baik, (Jakarta: PT RajaGrafindo Persada, 2013), hlm. 47.

${ }^{30}$ Abdul Rachmad Budiono, Pengantar Ilmu Hukum, (Malang: Bayu Media, 2005), hlm. 158.
} 
Based on the description above, Permenkumham No. 17/2018 does not have legal force and binding force as a rule, so what remains in effect in the field is the KUHD. So that at this time, the one the registration of deed of establishment of Limited Partnershipregistration of the deed of establishment of CV is in the registrar of the district court in accordance with the legal domicile of $\mathrm{CV}$, unless the regulations regarding the registration of deed of establishment of Limited Partnershipare ordered by law which is at the same level as the KUHD, if this is the case then what applies is the principle "Lex post teriori derogat legi priori", which means that: "The new statutory regulations have overridden or abolished the validity of the old statutory provisions which have regulated the same legal material". So that if there is a conflict between the old laws and regulations, the new laws and regulations will prevail.

So from the description above, it can be said that the position of Permenkumham No. 17/2018 putting aside Article 23 of the KUHD which contradicts Article 7 of Law no. 12/2011. This means that the registration of deed of establishment of Limited Partnershipfrom the District Court Panitra to the Ministry of Law and Human Rights is invalid because the Government does not comply with the principles.

\section{CONCLUSION}

Lower laws must not contradict higher laws and every statutory regulation must have a legal basis upon which to form a statutory regulation.

Therefore, the legality of the authority to record the registration of deed of establishment of Limited Partnershipfrom the District Court to the Ministry of Law and Human Rights is invalid, because the registration of deed of establishment of Limited Partnershipwhich is regulated in Permenkumham No. 17/2018, hierarchically contrary to the provisions of Article 7 Paragraph (1) of Law no. 12/2011. Because based on Article I of the Transitional Rules of the 1945 Constitution, the KUHD is still recognized as law in Indonesia. This means that the position of the KUHD is based on the principle of "lex superior derogat legi inferior", higher than Permenkumham No. 17/2018.

\section{REFERENCES}

Abdul Rachmad Budiono, Pengantar Ilmu Hukum, Malang: Bayu Media, 2005.

"All About Perseroan Komanditer (CV)-Pengertian, Seluk Beluk, dan Cara Mendirikan", www.kaskus.co.id/, diakses tanggal 27 Februari 2020.

Bagir Manan, Hukum Positif Indonesia, Yogyakarta: UII Press, 2004.

Bambang Sunggono, Metodoligi Penelitian Hukum: Suatu Pengantar, Cetakan keempat, Jakarta: PT RajaGrafindo Persada, 2002.

Bernard Arief Sidharta, "Penelitian Hukum Normatif: Analisis Penelitian Filosofikal dan Dogmatikal", dalam Sulistyowati Irianto dan Shidarta (Editor), Metode Penelitian Hukum Konstelasi dan Refleksi, Cetakan kedua, Jakarta: Yayasan Pustaka Obor Indonesia, 2011.

H. Salim, HS dan Erlies Septiana Nurbani, Penerapan Hukum Pada Penelitian Disertasi dan Tesis, Jakarta: PT. RajaGrafindo Persada, 2014.

I Kadek Setiawan, "Inkonsistensi Pengaturan dalam Pelaksanaan Kewenangan dan Biaya Pemberian Izin Usaha Mikro", Jurnal Legislasi Indonesia, Vol. 14, No. 3, 2017.

Johannes Ibrahim Kosasih dan Anak Agung Sagung Laksmi Dewi, Problematika Perseroan Komanditer (Commanditaire Vennootschap/CV) Dalam Ranah Hukum Bisnis dan Perbankan, Bandung: PT. Refika Aditama, 2019.

"Kedudukan Peraturan Menteri Dalam Hierarki Peraturan Perundang-undangan", https://m.hukumonline.com, diakses tanggal 5 Agustus 2020. 
Kementerian Koordinator Bidang Perekonomian Republik Indonesia, Pokok-pokok Isi Peraturan Pemerintah Nomor 24 Tahun 2018, Semarang 25 Juli 2018.

Ketut Caturyani Maharni Partyani, "Pertentangan Norma Dalam Pengaturan Pendaftaran dan Pendirian Commanditaire Vennootschap (CV)", Vyavahara Duta Jurnal Ilmiah Ilmu Agama dan Ilmu Hukum, Vol. 14 No. 1, Maret 2019.

Maria Farida Indriati, Ilmu Perundang-Undangan 1, Jakarta: Kanisius, 2013.

Peter Mahmud Marzuki, Penelitian Hukum, Cetakan ke 6, Jakarta: Kencana, 2010.

Ramlan, Eka NAM Sihombing, Fajriawati, Muhammad Iqbal, "Registration Legality of Deed of Establishment Through System Administration of Enterprise (The Analysis of Ministry of Law and Human Rights Regulation No. 17 of 2018)", Palarch's Journal of Archaeology of Egypt/Egyptology,Pjaee, 17 (4), 2020.

Ramlan, Hukum Perusahaan; Jenis-jenis Perusahaan di Indonesia, Medan: CV. Pustaka Prima, 2019.

-----------, Hukum Dagang; Perkembangan Buku Kesatu Kitab Undang-Undang Hukum Dagang Indonesia, Malang: Setara Press, 2016.

Rini Fitriani. "Aspek Hukum Legalitas Perusahaan atau Badan Usaha dalam Kegiatan Bisnis”, Jurnal Hukum Samudra Keadilan. Vol. 12, No. 1, 2017.

Rusdianto Sesung dan Muhammad Iqbal, "Legal Consequences Embedded on the Charity Institution Due to Uncompleted Synchronization Based on Constitution Number 28 Year 2014", International Jurnal of Science and Research (IJSR), Vol. 7, Issue 2, 2018.

Soerjono Soekanto dan Sri Mamudji, Penelitian Hukum Normatif Suatu Tinjauan Singkat, Cetakan Keenam, Jakarta: RajaGrafindo Persada, 2003.

Yuliandri, Asas-Asas Pembentukan Peraturan Perundang-Undangan Yang Baik, Jakarta: PT RajaGrafindo Persada, 2013.

Zainal Asikin dan Wira Pria Suhartana, Pengantar Hukum Perusahaan, Cimanggis Depok: Prenadamedia Group, 2016.

Zaka Firma Aditya dan M. Reza Winata, "Rekonstruksi Hierarki Peraturan Perundangundangan di Indonesia”, Jurnal Negara Hukum, Vol. 9, No. 1, 2018. 